\title{
Analisis Yuridis Kriminologis Tindak Pidana Pembunuhan Kepala Desa Parado Rato \\ (Studi Kasus di Kecamatan Parado Kabupaten Bima Provinsi Nusa Tenggara Barat)
}

\author{
Baharudin \\ Dosen STKIP Al Amin Dompu \\ Baharudinbimo99@gmail.com
}

\begin{abstract}
Abstrak. Penulisan ini dilatar belakang terjadinya pembunuhan seorang kepala desa Parado rato yang terjadi di Kecamatan Parado kabupaten Bima pada tahun 2016 yang lalu. Berdasarkan hal tersebut, penulisan hukum in mengangkat rumusan masalah yakni apa yang menjadi faktor penyebab terjadinya tindak pidana pembunuhan kepala desa parado rato, Bagaimana modus operandi tindak pidana pembunuhan Kepala Desa Parado Rato, Bagaimana Reaksi Masyarakat terhadap tindak pidana pembunuhan Kepala Desa Parado Rato dan Apakah kendala kepolisian dalam menanggulangi tindak pidana pembunuhan kepala Desa Parado Rato. Dalam pembunuhan tersebut dendam merupakan factor utama dalam pembunuhan tersebut disamping factor ekonomi, lingkungan, alkohol, dan kesalahan korban. Dalam pembunuhan tersebut membuat masyarakat kedua desa yaitu Desa parado wane dan desa parado rato sempat terjadi konflik sebagai bentuk reaksi terhadap terjadinya pembunuhan kepala desa tersebut. Sarana dan prasarana, Sumber Daya Manusia institusi kepolisian, budaya masyarakat dan sulitnya mendapat keterangan dari masyarakat adalah yang menjadi kendala kepolisian dalam menanggulangi tindak pidana pembunuhan kepala desa rato.
\end{abstract}

\section{Kata kunci : kriminologis, tindak pidana, pembunuhan}

\section{PENDAHULUAN}

Kejahatan senantiasa saja muncul silih berganti dan tidak pernah hilang dari muka bumi. Salah satu kejahatan yang dapat mengganggu keseimbangan hidup, keamanan, dan ketertiban dalam pergaulan masyarakat adalah pembunuhan. Perilaku kejahatan ini (criminal behaviour) bisa dilakukan oleh siapa saja, orang sehat, orang miskin, orang kaya, penderitan gangguan jiwa, perorangan, kelompok, pria, wanita, orang tua dan anakanak. Tegasnya setiap manusia dapat melakukan kejahatan. Kejahatan terhadap jiwa seseorang menimbulkan akibat mati, akibat matinya seseorang ini dilarang dan diancam dengan hukuman oleh undang-undang. Istilah tindak pidana dalam bahasa Belanda dapat disebut sebagai "strafbaarfeit" yang berarti suatu perbuatan yang menjadikan pelakunya dipidana. Pengertian tindak pidana adalah perbuatan atau tindakan melawan hukum yang berlaku, baik itu pelanggaran atau kejahatan yang dapat dituntut dengan hukum pidana atau ketentuan peraturan perundang-undangan. Pembunuhan adalah berupa penyerangan terhadap nyawa orang lain. Untuk menghilangkannya nyawa orang lain tersebut, maka seorang harus melakukan sesuatu atau suatu rangkaian tindakan yang berakibatkan dengan meninggalkan orang lain. Secara umum pembunuhan dapat diartikan sebagai tindakan atau tingkah laku manusia yang mengkibatkan hilangnya nyawa orang lain. Sebagaimana pembunuhan menewaskan seorang Kepala Desa Parado Rato yang terjadi di kecamatan Parado Kabupaten Bima tersebut merupakan perbuatan melawan hukum materiil. Perbuatan tersebut diatur dalam Kitab Undang-Undang hukum Pidana (KUHP). Ketentuan-ketentuan pidana tentang kejahatan yang ditujukan terhadap nyawa orang lain diatur dalam buku ke II Bab XIX, yang terdiri dari 13 pasal, yakni pasal 338 sampai pasal 350. Kejahatan terhadap nyawa orang lain terbagi atas beberapa jenis, 
yaitu pembunuhan biasa (pasal 338), pembunuhan dengan pemberatan (pasal 339), pembunuhan berencana yang diatur pasal 340.

\section{J. Michael dan M.J Adler (Crime, Law} and Criminologie) berpendapat bahwa kriminologi adalah ilmu pengetahuan yang mempelajari segala tingkah laku dan sifat penjahat, keadaan sekitar dan cara bagaimana penjahat-penjahat itu secara resmi atau tak resmi diperlakukan oleh badan-badan kemasyarakatan dan warga-warga masyarakat serta meliputi keseluruhan pengetahuan berdasarkan teori atau pengalaman, yang bertalian dengan perbuatan jahatdan penjahat, termasuk di dalamnya reaksi dari masyarakat terhadap perbuatan dan para penjahat. Hal ini serupa dengan kasus pembunuhan di kabupaten Bima. Kasus tersebut menimpa Mansyur, SH, korban adalah seorang kepala desa Rato kecamatan Parado kabupaten Bima, kejadian tersebut terjadi pada selasa sore tanggal 25 Oktober 2016 sekitar pukul 16.50 Wita. Peristiwa tersebut terjadi di ujung timur desa parado wane tepatnya di depan SMPN 1 Parado Kecamatan Parado. Korban bersama istrinya yang saat itu mengendarai mobil sedan miliknya dicegat oleh \pm 10 orang pemuda yang sedang menggelar mesta miras, salah satu dari mereka memukul body mobil korban, memaksa korban turun dari mobilnya. Setelah korban turun dari mobilnya langsung dibacok, dan mereka melarikan diri di hutan.

\section{Rumusan Masalah}

Pertama, Apa yang menjadi faktor penyebab terjadinya tindak pidana pembunuhan Kepala Desa Parado Rato. Kedua. Bagaimana modus operandi tindak pidana pembunuhan Kepala Desa Parado Rato. Ketiga, Bagaimana Reaksi Masyarakat terhadap tindak pidana pembunuhan Kepala Desa Parado Rato. Keempat, Apakah kendala kepolisian dalam menanggulangi tindak pidana pembunuhan kepala Desa Parado Rato?.

\section{Tujuan Penelitian}

Penelitian ini bertujuan untuk: mengetahui factor penyebab terjadinya tindak pidana pembunuhan Kepala Desa Parado Rato. Mengatahui modus operandi tindak pidana pembunuhan Kepala Desa Parado Rato. Mengatahui Reaksi Masyarakat Parado Rato terhadap tindak pidana pembunuhan Kepala Desa Parado Rato, serta Ingin mengetahui kendala kepolisian dalam menaggulangi tindak pidana pembunuhan kepala Desa Parado Rato.

\section{METODE PENELITIAN}

Motode yang digunakan dalam penulisan ini adalah Yuridis Kriminologis. Teknik pempulan data digunakan dalam penelitian ini adalah Studi dokumen merupakan langkah awal dari setiap penelitian hukum, Wawancara adalah situasi peran antara pribadi bertatap muka (face to Face), yang berkaitan dengan kasus pembunuhan kepala Desa parado rato. Studi literature, dan Studi internet yaitu Dokumentasi (dokumnetasi study) dan Studi Kepustakaan (bibliography study).

Penelitian ini menggunakan sumber hokum Skunder (Secindary Data) merupakan sumber data penelitian yang di peroleh peneliti secara tidak langsung melalui media perantara, sumber hukum Primer (Primary Data) adalah sumber data yang diperoleh langsung dari sumber asli (tidak melalui media perantara), dan tersier sebagai bahan hukun tersier yaitu bahan yang memberikan petunjuk maupun penjelasan terhadap bahan hokum primer dan bahan hukum sekunder seperti yang dijelaskan dalam eknsiklopedia, kamus hokum, kamus bahasa Indonesia dan sebagainya.

Analisin data yang digunakan dalam penulisan ini adalah Analisis Diskripsi Kualitatif yaitu menganalisis data yang didasarkan pada kualitas data yang digunakan untuk memecahkan permasalahan pokok penelitian, kemudian diuraikan dalam bentuk bahasa deskriptif, yaitu suatu metode yang menghasilkan analisis dan berdasarkan apa yang dinyatakan oleh responden secara tertulis 
maupun lisan, untuk kemudian ditarik generalisasi yang seruas mungkin ruang lingkupnya.

\section{HASIL DAN PEMBAHASAN}

\section{Faktor-faktor Terjadinya Pembunuhan Kepala Desa Parado Rato}

Terjadinya suatu tindak pidana pembunuhan banyak sekali faktor-faktor yang melatar belakanginya. Selain faktor dari diri pelaku sebagai pihak yang melakukan suatu tindak pidana pembunuhan, banyak faktor lain yang mendorong dapat terjadinya suatu tindak pidana pembunuhan.yang terjadi dalam masyarakat.

Terdapat beberapa faktor utama yang menyebabkan dapat terjadinya suatu tindak pidana pembunuhan adalah sebagai berikut :

\section{Faktor Ekonomi}

Faktor kemampuan ekonomi di dalam keluarga termasuk salah satu faktor yang menyebabkan bagaimana pelaku dengan mudahnya terlibat tindak kejahatan yang bahkan tergolong berat Sebab pelaku pembunuhan yg tumbuh dalam keluarga yang serba kekurangan seringkali akan terbatas dalam mendapatkan sesuatu yang diinginkan.

Ekonomi telah menjadi isu yang menjadi penyebab terjadinya kejahatan, karena ketidakmampuan seseorang dalam mencukupi kebutuhan hidupnya jelas memiliki korelasi secara langsung dengan perbuatan kejahatan yang dilakukan. Dalam kejadian pembunuhan kepala Desa Parado Rato tersebut berawal dari sekelompok pemuda yang tidak mampu mencari uang untuk tambahan membeli minuman keras dalam pesta yang mereka laksanakan.

Tewasnya kepala Desa Parado Rato itu akibat dari korban melakukan larangan atau menolak memberikan sejumlah uang yang diminta oleh sekelompok remaja tersebut, sehingga pelaku tidak terima atas ponalakan yang dilakukan oleh korban, karena korban juga sebagai aparat desa yang merupakan kewajiban untuk mengahalau akan terjadinya kriminalitas maka, korban ingin membubarkan kelompok yang melakukan pesta minuman keras tersebut, akan tetapi penolakan untuk memberikan uang serta pembubaran yang dilakukan korban mendapat perlawanan dari pelaku.

Durkheim mempercayai bahwa hasrathasrat manusia adalah tak terbatas,satu "insatiable and bottomless abyss" (jarang yang tak pernah puas dan tak berdasar). Karena alam tidak mengatur batas-batas biologi yang ketat untuk kemampuan manusia sebagaimana ia mengatur makhluk lain seperti binatangbinatang, kita mengembangkan aturan-aturan social yang meletakkan suatu takaran yang realistis di atas aspirasi-aspirasi kita. Aturanaturan ini menyatu dengan kesadaran individu dan membuatnya menjadi merasa terpenuhi. Akan tetapi, dengan satu ledakan kemakmuran yang tiba-tiba, harapan-harapan orang menjadi berubah. Manakala aturan-aturan lama tidak lagi menentukan bagaimana ganjaran/penghargaan didistribusikan kepada anggota-anggota masyarakat itu, maka disana sudah tidak ada lagi pengekang/pengendali atas apa yang dinginkan. Sekali lagi system ini akan menjadi runtuh.

Menurut penulis, ekonomi menjadi salah satu faktor yang menjadi pembunuhan, awal terjadinya pembunuhan Kepala Desa Parado Rato, dikarenakan pelaku untuk mendapatkan sesuatu apa yang diinginkan harus menempuh berbagai cara untuk mendapatkannya, dalam hal kasus ini, sekelompok remaja terpaksan melakukan pemalakan kepada setiap pengendara yang melintas didepan mereka untuk menagih sejumlah uang. Dari hasil pemalakan tersebut pelaku dan kawan-kawan hasilnya untuk membeli beberapa botol minuman keras. Tidak semua pengendara atau orang yang ditagi/malak akan mengikuti pemintaan pelaku, ada juga yang menolak permintaan pelaku dan kawan-kawannya, karena penolakan dari dari korban pemalakan membuat Pelaku akan melakukan hal yang nekat termasuk membunuh. 


\section{Faktor Lingkungan}

Berkembangnya kehidupan dalam suatu masyarakat yang menimbulkan berbagai masalah social membuktikan bahwa kehidupan manusia semakin sulit, keadaan tersebut tidak mudah dihadapi sehingga akhirnya menyebabkan penyimpangan tingkah laku dalam suatu masyarakat (deviant), kemudian orang bertingkah laku dengan melanggar norma-norma yang berlaku dan berbuat sekehendak dirinya sendiri untuk mencapai kepuasan dan ang kepentingan sendiri tanpa memperhatikan hak-hak kepentingan orang lain.

Lingkungan masyarakat yang kurang memperhatikan norma-norma yang berlaku termasuk rendahnya pendidikan dan pengetahuan juga berakibat bagi seseorang untuk melakukan tindak kejahatan. Hal demikian disebabkan oleh kurangnya control social dari lingkungannya. Apalagi masyarakat kita terdiri dari kelompok dan sub kelompok yang berbeda-beda, masing-masing dengan standar atau ukuran benar dan salahnya sendiri. Tingkah laku dianggap normal di satu masyarakat mungkin di anggap menyimpang oleh kelompok lain.

Dalam kejadian pembunuhan yang terjadi di Kecamatan Parado tersebut, masyarakat jarang sekali melakukan control atau menegur setiap tindakan pelaku yang selalu melanggar normanorma yang berlaku dimasyarakat, sehingga pelaku merasa bebas karena tidak ada control dari masyarakat sekitarnya. Masyarakat juga kurang tegas dalam menjalankan aturan adat yang berlaku dalam masyarakat. Prilaku mabuk-mabukan dan krimanal lainya sering terjadi didalam masyarakat karena masyarakat tidak bisa memberikan pandangan dan teguran yang bisa merubah atau menyadari para pelaku criminal.

Kekwatiran orang-orang akan terjadi hal-hal yang bisa mengancam kemanannya adalah factor yang sering terjadi dalam masyarakat, karena peneguran dan larangan masyarakat terhadap criminal yang teradi akan berimbas permusuhan bahkan ancamanpun pasti terjadi apabilan masyarakat terlalu ikut campur dalam pelaku criminal kerjakan.

Travis Hirschi Guru besar University of Arozona berpedapat bahwa perilaku krimial merupakan kegagalan kelompok social konvesional, seperti keluarga, sekolah, kawan sebaya untuk mengikat atau terikat dengan indvidu. Jadi masyarakat tidak tidak bisa merangkul, mendekatakan diri secara emosional atau memberikan arahan kepada pelaku kejahatan bahwa apa yang diperbuat itu adalah suatu tindakan yang melannggar normanorma yang ada dalam masyarakat, sehingga pelaku pembunuhan Kepala Desa Parado Rato tersebut bebas melakukan sesuatu walaupun perbuatan tersebut dianggap melanggar suatu norma yang berlaku dimasyarakat.

\section{Faktor Alkoholisme}

Alkoholisme yang akut, adalah terutama berbahaya, karena ia menyebabkan hilangnya daya menahan diri dari sepeminum. Bahwa alkohol jika dipergunakan maka akan membahayakan manusia pertama-tama didalam jiwanya paling lemah. Dan apabila alkohol dipergunakan oleh orang yang mempunyai sifat agresif apabila meminum minuman beralkohol akan mudah melakukan perbuatan kekerasan.

Masalah alkolisme dan pemabuk pada kebanyakan masyarakat pada umumnya tidak berkisar pada apakah alkohol boleh atau dilarang dipergunakan. Umumnya orang awam berpendapat bahwa alkohol merupakan suatu stimulant, padahal sesungguhnya alkohol merupakan racun protoplasmic mempunyai efek depresan pada system syaraf. Akibatnya, seorang pemabuk semakin kurang kemamampuan mengendalikan diri, baik secara fisik, psikologis maupun social.

Pada saat terjadinya pembunuhan Kepala Desa Parado Rato, pelaku tidak bisa mengontrol emosinya karena pelaku sudah banyak meminum minuman yang beralkohol, sehingga kemampuan untuk mengendalikan diri atau mengendalikan emosi tidak bisa dikontrol lagi, rasa takut yang biasa dialami oleh pelaku 
pembunuhan sudah tidak ada, sifat agresif untuk mendapatkan sesuatu yang korban inginkan tidak dapat diraih karena ada penolakan dari korban pembunuhan.

Barangkali ini harus diterangkan, bahwa rasa takut yang sudah tertanam pada kita terhadap alat kekuasaan Negara yang penuh rasa tunduk yang harus dimiliki oleh rakyat yang demokratis terhadap pemerintah yang sudah dipilih sendiri. Rasa tunduk terhadap pemerintah yang sah sudah tidak ada lagi apabila alkohol atau minuman keras sudah menguasai syaraf atau pikiran kita, maka tindakan yang melanggar norma-norma akan dilakukan tanpa adanya rasa takut.

\section{Faktor Dendam}

Hal ini bermula ketika pelaku mengetahui bahwa orang yang ikut melakukan pembunuhan terhadap Ahmad Manan (Paman Pelaku) masih bisa menghirup udara segar dan belum ditangkap oleh pihak kepolisian, hal ini dikarenakan pelaku pembunuhan Ahamd Manan sengaja disembunyikan oleh Mansyur Umar, SH (Kepala Desa Parado Rato).

Pelaku yang merasa dendam dan merasa memiliki tanggung jawab untuk menyelesaikan persoalan keluarganya akhirnya memilih membunuh korban. Korban yang merupakan Seorang Kepala Desa yang kembali dari Desa Tente selesai membayar cicilan kredit Motor, kemudian di dalam perjalanann Korban bersama istrinya di tahan oleh beberapa anak muda di jembatan Dana Me'E (Jembatan Tanah Hitam) sebelum masuk Desa Parado Wane, karena tidak terima ditahan, korban turun dari mobil dan memarahi para pemuda yang menahannya, setelah selesai memarahi korban kembali ke dalam mobil, karena ada rasa dendam pelaku memukul bagian belakang mobil korban karena tidak terima dengan perlakuan pelaku maka korban turun lagi dari mobil pada saat itulah keduanya saling berkelahi, karena pelaku tidak mampu mengimbang perkelahian dengan tangan kosong maka pelaku mengambil parang (cila
Goa) yang tersimpan diatas jembatan dan langsung membacok korban.

Dendam merupakan sebab dan latar belakang terjadinya banyak kejahatan, termasuk penganiayaan dan pembunuhan. Ini disebabkan karena dendam merupakan sesuatu yang sangat sulit untuk dipulihkan terhadap manusia yang pernah merasa sakit hati terhadap perlakuan seseorang terhadapnya atau keluargannya. Sebab sesuai dengan faktor-faktor penyebab tidak langsung yang telah dijelaskan diatas, kehidupan manusia pada zaman sekarang memiliki banyak problem yang sudah tergolong kompleks sehingga tidak menutup kemungkinan apa yang difikirkan dan dirasakan oleh orang dewasa.

Pembunuhan yang terjadi di Kecamatan Parado tersebut merupakan lanjutan konflik intern yang terjadi pada tahun 2015 silam, pelaku sangat marah dan mempertahankan harga dirinya setelah korban turun dari mobil dan memarahi pelaku, apalagi diketahui korban dianggap ikut andil dalam pembunuhan 2015 lalu. Dalam kejadian itu pelaku tidak bisa menahan diri untuk membalas apa yang korban perbuat terhadap keluarganya, apalagi dalam keadaan mabuk hasrat untuk melakukan balas dendam semakin tinggi dan tidak bisa ditahan lagi.

Dari hasil penelitian penulis, Dendam adalah bagian dari emosi. Emosi seringkali bersifat fluktuatif dan dinamis, tergantung penghayatan seseorang terhadap situasi dalam hidupnya. Orang yang merasa dendam maka kondisi jiwanya tak stabil, sehingga hidupnya tak merasa tenang. Dendam ialah suatu perasaan sakit hati, kekecewaan, kekesalan, amarah, atau kepahitan karena ketidakmampuan seseorang untuk bisa menerima dan memaafkan perlakuan buruk dari orang lain. Perasaan dendam yang sulit diatasi dengan baik, akan tersimpan dalam hati. Dendam merupakan energi psikoemosional yang bersifat negatif bila pelampiasannya mengorbankan orang lain. namun kalau dendam tidak dilampiaskan (dikeluarkan) dengan baik, 
maka dendam akan menumpuk dan menjadi boomerang bagi diri sendiri.

\section{Faktor Kesalahan Korban}

Apabila kita hendak mencari solusi sebagai upaya penanggulangan kejahatan yang tepat, maka cara pandang kita sebaiknya tidak hanya terfokus pada berbagai hal berkaitan dengan penyebab timbulnya kejahatan atau metode apa yang efektif untuk dipergunakan dalam penanggulangan kejahatan, namun hal lain yang tidak kalah pentingnya untuk dipahami dan diperhatikan adalah masalah korban kejahatan itu sendiri, yang dalam keadaan-keadaan tertentudapat menjadi pemicu munculnya kejahatan.

Pada hal ini, peran korban merupakan hal paling yang fungsional dalam terjadinya suatu kejahatan, menurut Arif Gosita. Kenyataanya dapat dikatakan bahwa tidak mungkin timbul suatu kejahatan apabila tidak ada korban kejahatan yang merupakan peserta utama dari si penjahat dalam hal terjadi suatu kejahatan.

Menurut Colin Shepard, seperti dikutip oleh Mulayana W. Kusumah mengungkapkan bahwa lebih dari 2/3 kejadian pembunuhan dan penyerangan (assaults) memang didahului oleh adanya suatu hubungan antara dua pelaku dalam kejadian tersebut, sebelum berlangsungnya kejahatan. Seringkali hal ini dilukiskan sebagai kekerasan domestik, dan yang paling sering terjadi dalam kejadian terungkap bahwa korban merupakan peran kunci dalam interaksi kekerasan, seringkali memprovokasi orang lain atau sering juga mencetuskan saling balas dengan kekerasan yang pada ujungnya berakhir dengan kematian.

Melihat beberapa teori diatas, hubungan sosial korban seringkali dipandang sebagai pemicu terhadap situasi-situasi yang melahirkan kejahatan, bahkan sebagai faktor pencetus. Dengan demikian antara pihak korban dengan pelaku terdapat hubungan yang fungsional untuk melahirkan kejahatan.

Pada umumnya dikatakan hubungan korban dengan kejahatan adalah pihak yang menjadi korban sebagai akibat kejahatan.tentu ada asap pasti ada api. Pihak tersebut menjadi korban karena ada pihak lain yang melakukan kejahatan. Memang demikianlah pendapat yang kuat selama ini yang didukung dengan fakta yang ada, meskipun dalam praktik ada dinamika yang berkembang.

Menurut penulis, pembunuhan tersebut bukan karena ada niat murni dari pelaku untuk membunuh korban, akan tetapi karena korban sudah mengatakan ancaman seperti itu maka pelaku yang pada saat itu masih dalam keadaan mabuk akhirnya marah dan emosinya makin tinggi, apalagi korban masih ada rasa dendam kepada korban yang telah melindungi pelaku pembunuhan Abdul Manan (paman pelaku) sampai sekarang belum juga tertangkap.

\section{Kendala Kepolisan Dalam Menanggulangi Tindak Pidana Pembunuhan Kepala Desa Parado Rato}

Kepolisian merupakan lembaga hokum dan hidup dalam komunitas manusia yang lebih besar yang dapat membentuk segala sesuatu yang dilakukan oleh organisasi, maka peletakan lembaga kepolisian dalam suatu organisasi Negara menjadi lebih penting, karena akan mempengaruh terhadap pelaksanaan tugas dan tanggung jawab yang dibebankan serta kinerja (performance) lembaga kepolisian. Karena itu ketidak tepatan dalam memposisikan lembaga kepolisian dalam ketatanegaraan akan menciptakan problematika bagi lembaga kepolisian tersebut dalam menjalankan tugas dan wewenangnya sebagai kepolisian Negara.

Adapun kendala-kendala yang dihadapi oleh pihak kepolisian dalam manggulangi tindak pidana yang terjadi di kecamatan parado antara lain:

\section{Kendala Internal}

\section{a. Sarana dan Prasarana}

Sarana atau fasilitas mempunyai peranan yang sangat penting di dalam penegakan hukum karena tanpa adanya sarana atau fasilitas tersebut, tidak akan mungkin penegak hukum menyerasikan peranan yang seharusnya dengan peranan yang aktual. Tanpa adanya sarana atau 
fasilitas tertentu, tidak mungkin penegakan hukum akan berlangsung dengan lancar dan mencapai tujuannya. Sarana atau fasilitas tersebut, antara lain mencakup tenaga manusia yang berpendidikan dan terampil, organisasi yang baik, peralatan yang memadai, keuangan yang cukup, dan seterusnya.

Tanpa adanya sarana atau fasilitas tertentu, tidak mungkin penegakan hukum akan berlangsung dengan lancar dan mencapai tujuannya. Sarana atau fasilitas tersebut, antara lain mencakup tenaga manusia yang berpendidikan dan terampil, organisasi yang baik, peralatan yang memadai, keuangan yang cukup, dan seterusnya.

Kendaraan dinas untuk melakukan patroli yang dimiliki oleh KAPOLSEK parado masih minin, jadi kalau kendaraan dinas melakukan patroli di desa parado Lere yang jaraknya $15 \mathrm{Km}$ dari Kota Kecamatan maka, pesonil yang lain tidak bisa melakukan patroli ke desa lain yang ada di kecamatan parado dan juga personelnya masih kurang untuk melakukan patroli di desa-desa yag lain. Sehingga kegiatan untuk mengamankan dan memantau kejadian yang dianggap sebagai suatu tindak pidana tidak bisa dilakukan secara maksimal yang sesuai dengan harapan masyarakat.

Menurut Walter C. Recless terdapat beberapa syarat agar penanggulangan kejahatan yang dilakukan pihak kepolisian dapat dikatakan berhasil, yakni system organisasi kepolisian yang baik. Kemudian dari sisi sarana, Kapolri juga menjelaskan, sarana ini terdiri dari kegiatan kepolisian, opersional kepolisian, dan kerjasama kepolisian. Kegiatan kepolisian diarahkan pada, segala bentuk gangguan keamanan pada tahap pembiakan dini; segala bentuk gangguan kemanan yang belum terjadi tetapi telah meresahkan masyarakat karena diperkirakan akan terjadi; dan gangguan nyata dalam bentuk kejahatan dan pelanggaran yang terjadi di masyarakat.

\section{SDM (Kepolisian)}

Kendala selanjutnya adalah Sumber daya manusia, dalam melaksanakan tugas dan wewenang kepolisian SDM kepolisian yang sangat penting dalam mengungkapkan suatu kejahatan dalam masyarakat. Untuk itu dalam menjalankan tugas dan fungsinya kepolisian harus mempunyai personil dan wawasan yang siap melayani dan mengayomi masyarakat.

Kaitanya dengan kendala diatas menurut Achmad Ali yang menyatakan Bahwa, Memang tidak dapat disangka kendala yang dihadapi pihak kepolisian kita adalah keterbatasan kepolisian Indonesia menanggulangi berbagai jenis kriminalitas. Faktor penyebabnya salah satu adalah tidak terlepas dari belum berimbangnya antara jumlah personil polisi dengan jumlah warga masyarakat yang harus dilayani.

Rekrutmen menjadi salah satu faktor penting untuk membangun SDM. "Kalau salah rekrut, untuk memindahkan nanti akan jadi persoalan internal," Polri harus memilih sekian juta masyarakat untuk menjadi anggota Polri. Ke depan, tahapan seleksi dilaksanakan transparan dari pendaftaran hingga pengumuman. Sehingga setelah jadi anggota Polri, tidak ada pelanggaran yang dilakukan.

\section{Kendala Eksternal \\ Budaya Hukum Mayarakat}

Kesadaran hukum masyarakat sangat penting dalam penegakkan hukum, peran aktif masyarakat dalam menginformasikan kepada pihak penegak hukum sangat mempengaruhi dalam pelaksanaan peran kepolisian dalam menanggulangi tindak pidana. seringkali masyarakat tidak memahami bahwa kejahatan semakin tumbuh apabila masyarakat selalu acuh tak acuh dalam melaporkan segala kegiatan yang di anggap anti sosial atau melanggar norma dalam masyarakat kepada penegak hukum.

Perlunnya kepolisian untuk secara konsisten dan konsekwen melakukan pembanahan bertujuan agar kepolisian mampu 
menjaga eksistensinya di tengah perubahan lingkungan yang begitu cepat, mengingat polri dalam kiprahnya senantiasa dihadapkan pada beragam tantangan yang semakin berat dan kompleks. Sekalipun demikian, ditengahtengah pembenahan yang dilakukan polri harus berhadapan dengan kritikan/cacian dari masyarakat, terkait performa dari anggota/institusi yang dianggap belum sesuai dengan harapan masyarakat.

Penegakan hukum berasal dari masyarakat dan bertujuan untuk mencapai kedamaian di dalam masyarakat sehingga masyarakat dapat mempengaruhi penegakan hukum tersebut. Masyarakat mempunyai kecenderungan yang besar untuk mengartikan hukum dan bahkan mengidentifikasikannya dengan petugas, dalam hal ini penegak hukum sebagai pribadi. Salah satu akibatnya adalah bahwa baik-buruknya perilaku penegak hukum tersebut, yang menurut pendapatnya merupakan pencerminan dari hukum sebagi struktur maupun proses.

Lingkungan masyarakat yang kurang memperhatikan norma-norma yang berlaku termasuk rendahnya pendidikan dan pengetahuan juga berakibat bagi seseorang untuk melakukan tindak kejahatan. Hal demikian disebabkan oleh kurangnya kontrol sosial dari lingkungannya. Trivis Hirschi berpendapat bahwa, perilaku kriminal merupakan kegagalan kelompok sosial konvesional, seperti keluarga, sekolah, kawan sebaya untuk mengikat atau terikat dengan individu.

Zainuddin Ali juga mengemukakan faktor-faktor yang dapat mempengaruhi efektivitas hukum di dalam masyarakat, yaitu kaidah hukum atau peraturan itu sendiri, petugas atau penegak hukum, sarana atau fasilitas yang digunakan oleh penegak hukum, dan kesadaran masyarakat. Usaha-usaha yang dapat dilakukan untuk meningkatkan kesadaran hukum masyarakat adalah dengan terlebih dahulu meningkatkan pengetahuan hukum, pemahaman hukum, penaatan hukum, dan pengharapan terhadap hukum.

Budaya masyarakat parado yang selama ini dikenal dengan julukan Paradise yang masyarakatnya ramah dan persaudaraan sudah terkikis dengan perkembangan jaman atau gaya hidup masyarakat yang begitu kompleks, sehingga budaya-budaya yang selama ini sebagai pengontrol kehidupan masyarakat parado sudah tidak lagi berfungsi dengan baik, sehingga tindakan yang melangggar budaya masyarakat tidak lagi ada yang mengatur karena kurang kerjasama disetiap komponen masyarakat.

Bagir Manan menyatakan bahwa, tidak terlalu tepat apabila penegakan hukum hanya bertumpu pada usaha menjalankan hukum yang dilakukan oleh aparat hukum. Pelibatan anggota masyarakat merupakan komponen penting dalam penegakan hukum, yakni pembentukan masyarakat yang taat pada hukum. Tampa ada usaha yang sistimatik mencapai tujuan masyarakat yang patuh dan taat hukum, penegakan hukum merupakan pekerjaan yang bersifat rutinitas belaka, tanpa dapat diukur tingkat keberhasilannya.

\section{Kesulitan dalam menemukan keterangan dari Masyarakat}

Penegakan hukum berasal dari masyarakat dan bertujuan untuk mencapai kedamaian di dalam masyarakat sehingga masyarakat dapat mempengaruhi penegakan hukum tersebut. Masyarakat mempunyai kecenderungan yang besar untuk mengartikan hukum dan bahkan mengidentifikasikannya dengan petugas, dalam hal ini penegak hukum sebagai pribadi. Salah satu akibatnya adalah bahwa baik-buruknya perilaku penegak hukum tersebut, yang menurut pendapatnya merupakan pencerminan dari hukum sebagi struktur maupun proses.

Struktur social tradisional yang melembaga dalam kehidupan masyarakat pedesaan, yang meliputi perasaan dan ikatan bathin yang berdasarkan statusnya, yaitu berdasarkan ikatan geneologis yang 
berkembang kearah kesatuan-kesatuan sosiopolitik yang bersifat teroterial dan kekerapatan; yang hidup dalam persekutuan hokum adat yang ada dalam masyarakat.

Dalam kasus pembunuhan kepala Desa Parado Rato tersebut banyak masyarakat yang melihat pelaku melakukan pembunuhan tersebut akan tetapi masyarakat tidak mau menjadi saksi, pada saat di mintai keterangan oleh pihak penyidik masyarakat sudah merasa takut, apalagi yang berhubungan dengan pihak kepolisian. Dalam masyarakat pedesaan, polisi merupakan instansi yang sangat menakutkan oleh sebab itu mereka memilih diam atau tidak terbuka dalam kasus pembunuhan kepala Desa Parado Rato tersebut.

Dengan demikian kepolisian sebagai "alat Negara" mengadung dua penafsiran, yakni positif dan negative. Penafsiran positif, karena tugas dan wewenang kepolisian menjaga atau memelihara kemanan dan ketertiban masyarakat, menegakan hukum, perlindungan, pengayoman dan pelayana kepada masyarakat, penekanannya adalah untuk kepentingan masyarakat, bangsa dan Negara. Sedangkan penafsiran negative, bahwa dalam kondisi tertentu atau sewaktu-waktu "penguasa" (dalam arti pimpinan politik yang sedang berkuasa) dapat menggunakan tindakan kepolisian untuk kepentingan politiknya.

\section{KESIMPULAN}

Berdasarkan hasil peneltian sebagaimana telah diuraikan dalam bab hasil dan pembahasan dapat ditarik kesimpulan sebagai berikut: Faktor Ekonomi merupakan masalah yang besar pengaruhnya terhadap setiap orang untuk melakukan kejahatan. Dalam pengamatan penulis dilapangan, bahwa kekurangan ekonomi untuk mendapatkan sesuatu pelaku inginkan memaksa pelaku untuk melakukan suatu pemalakan atau penagihan kepada setiap pengendara kendaraan yang lewat.

Faktor Psikologis dari pelaku termasuk yang paling dominan terhadap terjadinya kejahatan, psikologis dari pelaku kejahatan itu terdiri dari: (1) Alkohol, Dalam keadaan mabuk pelaku kejahatan tidak bisa mengontrol emosinya untuk melakukan suatu kejahatan. Karena dalam keadaan mabuk juga pelaku kejahatan akan semakin agresif dalam melakukan tindakan sehingga keinginan dalam melakukan kejahatan tidak bisa dikontrol lagi. (2) faktor dendam merupakan faktor yang sangan besar dalam melakuakan kejahatan, dendam kepada seseorang akan timbul apabila ada orang lain melakukan suatu tindakan yang menimbulkan sakit hati. Faktor Kesalahan dari korban merupakan timbulnya suatu kejahatan dimana pelaku akan melakukan kejahatan apabila ada sesuatu provokasi dari korban, bahwa korban merupakan peran kunci dalam interaksi kekerasan, seringkali memprovokasi orang lain atau sering juga mencetuskan saling balas dengan kekerasan yang pada ujungnya berakhir dengan kematian.

Modus meninggalnya korban pembunuhan tersebut pelaku menggunakan tangan untuk memukul dan menggunakan benda tajam sejenis parang untuk membacok korban sehingga korban mendapat luka dari dada sampai perut. Pelaku kejahatan akan medapatkan reaksi dari masyarakat diamana masyarakat akan melakukan suatu tindakan apabila ada kejahatan yang dianggap sebagai tindakan merusak kehidupan sosial dan melanggar norma-norma yang berlaku. Reaksi tersebut dapat berupa membalas pelaku dengan dengan kejahatan dan tapat juga ikut mencari pelaku kejahatan untuk diserahkan kepada pihak keamanan.

Kejadian pembunuhan tersebut juga banyak kendala yang dihadapi oleh pihak kepolisian antara lain: Faktor Internal. polri seperti sarana dan prasarana pendukung dalam melaksanakan tugas seperti kendaraan untuk melakukan Patroli tidak memadai sehingga sulit untuk melakukan suatu pengawasan terhadap kegiatan masyarakat, jaringan telekomikasi juga sangat penting dalam menanggulangi kejahatan. SDM juga merupakan faktor yamg menjadi penghambat dalam menanggulangi 
kejahatan, keterbatasan personel kepolisan dapat menghambat kinerja dalam menanggulangi kejahatan, yang paling krusial adalah cara perekrumen, pendidikan, pembinaan karier dan perawatan personel juga adalah hambatan dalam menanggulangi kejahatan. Faktor Eksteral. Budaya hukum masyarakat juga merupakan kendala dalam menanggulangi tindak pidana, dimana masyarakat banyak yang tidak mengetahui bahwa timbulnya suatu kejahatan berawal dari perbuatan-perbuatan yang kecil, tidak adanya peran aktif masyarakat dalam mengontrol setiap kegiatan sekelompok masyarakat yang dianggap melanggar norma-norma atau nilainilai yang beeraku dalam masyarakat.

\section{DAFTAR PUSTAKA}

A. Widiada Gunakaya, 1994, Diktat Kuliah Kriminologi, STHB, Bandung

Abdul Syani, 1987, Sosiologi Kriminal, Remadja Karya, Bandung

Abintoro Prakoso, 2013, Kriminologi dan Hukum Pidana,Laksbang Garafika,

Ahmad Ali, 1998. Menjelajahi kajian Empiris Terhadap Hukum. Jakarta : Yasti

Andi Hamzah, 1986, Hukum Pidana dan Acara Pidana, (Jakarta: Ghalia Indonesia

Bandung

Bonger, 1995, Pengantar Tentang Kriminologi, PT. Pembagunan,Jakarta

Grafindo Persada

http://hukumkepolisian.blogspot.co.id/2011/01/f aktor-faktor-yangmempengaruhi. html. 13/05/2017. Jam, 12.04

http://www.bimakini.com/2016/10/motifpembunuhan-kades-rato-dendamlama /2016/11/09.19.02

Kartini Kartono, 1980, Pathologi Sosial, Rajawali, Jakarta

Kejahatan, Sinar Baru, Bandung

M. Ali Zaidan, 2016, Kebijakan Kriminal, Sinar Grafika,Jakarta

Madiatama, Surabaya,

Mediatama, Surabaya

Jurnal Ilmu Sosial dan Pendidikan
Moeljanto, 1993, Asa-Asas Hukum Pidana, PT. Rineka Cipta, Jakarta

Mulyana W. Kusuma, 1984, kriminologi dan masalah Kejahatan (suantu Pengantar

Mulyana W. Kusumah, 1988, Kejahatan dan Penyimpangan Suatu Perspektif, YLBHI.

Ringkas), Bandung Armico

Romli Atamasasmita, 1983, Kapita Selekta Kriminologi, Armico. Bandung

Sadjijono, 2008, Seri Hukum Kepolisian (Polri dan Governance), Laksbang

Soedjono Dirdjosisworo, Sisio-Kriminologi Amalan Ilmu-Ilmu Sosial dalam Studi

Soejono Soekanto, Sosiologi Suatu Pengantar, Jakarta, PT. Rajagrafindo Persada

Sudarto.1990. Hukum Pidana I. Semarang: Yayasan Sudarto Fakultas Hukum

Teguh Prasetya, 2010, Kriminalisasi dalam Hukum Pidana, Cetakan 1, Nusamedia

Topo Santoso dan Eva Achani Zulfa, 2105, Kriminologi, Cetakan Kesepuluh, Raja

UNDIP

Watampone

Widjijono, 2008, Seri Hukum Kepolisian, POLRI dan Governance, Laksbang

Yogyakarta

Zainuddin Ali, 2014. Sosiologi Hukum (Jakarta: Sinar Grafika). 